\title{
P01-026 - A case of FMF and hereditary coproporphyria
}

\author{
A Ganesha*, S Savic \\ From 7th Congress of International Society of Systemic Auto-Inflammatory Diseases (ISSAID) \\ Lausanne, Switerland. 22-26 May 2013
}

\section{Introduction}

We report a unique case in a 17 year old male patient of Algerian origin with two rare genetic conditions with overlapping clinical symptoms. Familial Mediterranean fever (FMF) is an autosomal recessive disorder characterized by sporadic, paroxysmal attacks of fever and serositis. Hereditary coproporphyria (HCP) is one of the type of acute hepatic porphyria resulting in neurovisceral symptoms caused by deficient activity of mitochondrial enzyme coproporphyrinogen oxidase. Both are considered rare differential diagnosis for acute abdominal pain.

\section{Case report}

17 year old boy of Algerian origin presented with long history of recurrent episodes of fever, abdominal pain since infancy. He experiencied 3-4 attacks per year each lasting typically for 2-3 days. There was no family history.

Patient was referred simultaneously to immunology and metabolic medicine for further assessment. Differential diagnoses considered at the time included: periodic fever syndromes, hereditary angioedema, vasculitis and porphyria.

FBC results over the year showed intermittent leucocytosis during acute attacks with elevated C-reactive protein (CRP) and plasma viscosity (PV). Serum amyloid A (SAA) was not measured. Investigations during quiescent phase showed normal levels of SAA but slightly elevated CRP $13.4 \mathrm{mg} / \mathrm{l}(\mathrm{ref}<10)$ and neutrophilia of $9.9 \times 10^{9} / \mathrm{l}($ ref $2.00-$ 7.50).

Genetic investigations for periodic fever syndromes confirmed two pathogenic MEFV gene mutation on sequencing Exon 2 and 10 at p. (Met694IIe(;)Glu148Gln), supporting diagnoses of FMF. Sequencing for MVK and TNFRSF1A gene were negative.

\section{Clinical Immunology United Kingdom

Investigations undertaken by metabolic medicine specialists revealed urine coproporphyrin III at $42.75 \mathrm{nmol} /$ $\mathrm{mmol}$ cret (1.2-24.8) with porphrin/creat Ratio of 54.6 $\mathrm{nmol} / \mathrm{mmol}(\operatorname{Ref}<28)$. Faecal porphrin were $1639 \mathrm{nmol} /$ g dry weight $($ ref $<130)$ with faecal coproporphyrin III: I ratio at $19.51(\operatorname{Ref}<2)$. The results confirmed diagnosis of HCP. Genetic tests are awaited for the patient. He has management plan for hereditary coproporphyria.

Patient was commenced on colchicine at the dose of 500 micrograms twice daily. No further episodes of abdominal pain have been reported in the last 9 months since prophylaxis starting prophylaxis with colchicine.

\section{Discussion}

FMF and HCP are both recognised as rare causes of unexplained acute abdominal pain associated with fever. However there are several additional features which would favour FMF over HCP. The patient's ethic origin is more suggestive of FMF. The majority of HPC was reported in the North European ancestry. The onset of HCP also tends to be in puberty whilst FMF usually presents in childhood with initial attacks before the age of 10 in 65\% of cases. Low grade persistent inflammatory response is a feature of FMF and not necessarily seen HCP. Finally apparent response to colchicine would further support diagnosis of FMF.

\section{Disclosure of interest}

None declared.

\section{Published: 8 November 2013}

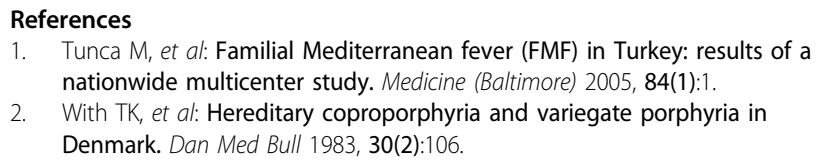


doi:10.1186/1546-0096-11-S1-A30

Cite this article as: Ganesha and Savic: P01-026 - A case of FMF and

hereditary coproporphyria. Pediatric Rheumatology 2013 11(Suppl 1):A30.

Submit your next manuscript to BioMed Central and take full advantage of:

- Convenient online submission

- Thorough peer review

- No space constraints or color figure charges

- Immediate publication on acceptance

- Inclusion in PubMed, CAS, Scopus and Google Scholar

- Research which is freely available for redistribution

Submit your manuscript at 